\title{
State Implementation of Welfare Law on Implementation of Human Rights in Local Governments
}

\author{
Agus Hamzah*) and Rakhmat Bowo Suharto**)
}

*) Student of Master of Law, Faculty of Law, Universitas Islam Sultan Agung Semarang, E-mail: aguslaw3000@gmail.com

${ }^{* *}$ ) Lecturer of Master of Law, Faculty of Law, Universitas Islam Sultan Agung Semarang

\begin{abstract}
.
The purpose of this study is to determine the indicators of the realization of the welfare state law through development program documents. The approach method used is normative juridical. The conclusion of this research is that the welfare law state is often referred to as a modern law state in a material sense in the sense that the state or government is not merely the guardian of security or public order, but is the main bearer of the responsibility to realize social justice, public welfare, and as much prosperity people. As the social contract theory put forward by John Locke, and also Rousseau, which states, that the state obtains power from citizens as the holder of sovereignty solely to respect, protect and fulfill the human rights of citizens, implemented according to the Basic Law, the embodiment of the welfare state stated in the preamble to the 1945 Constitution, namely protecting the entire Indonesian nation and all Indonesian bloodshed and to promote public welfare, educate the nation's life and participate in implementing world order, This national goal contains the vision of the Indonesian people in the field of human rights and subsequently brought down in the vision and mission stated in the Regional Long-Term Development Plan (RPJPD) and the Regional Medium-Term Development Plan (RPJMD) which contain the vision and mission which can be an indicator of the realization of a welfare state law.

Keywords : State Welfare Law; Human Rights; Local Government.
\end{abstract}

\section{Introduction}

Human rights in Islam are known as "huquq al-insan addhoruriyyah" and "huquq Allah". In Islamic teachings, "huquq al-insan addhoruriyyah" and "huquq Allah" cannot walk alone without attachment to one another. ${ }^{1}$ In the theory of social contracts put forward by John Locke, and also Rousseau, which states, that the state obtains power from citizens as the holder of sovereignty solely to respect, protect and fulfill the human rights of citizens. This conception then gave birth to the principle of democracy in which the state is "from the people, by the people, and for the people". The obligation to respect means that the state is obliged to avoid any intervention under any pretext to eliminate or reduce the rights of citizens. Meanwhile, the obligation to protect is an obligation to take active action to ensure that the rights of every citizen are not violated. Then the obligation to fulfill is the obligation to take legislative, administrative, justice and practice to ensure that the rights of citizens are properly exercised and fulfilled. Meanwhile,

\footnotetext{
1 Tim ICCE UIN Jakarta, 2003 Pendidikan Kewarganegaraan (Civic Education), Demokrasi, HAM dan Masyarakat Madani, Jakarta dan Prenada Media. p.200
} 
the obligation to promote can be carried out by providing education and dissemination of Human Rights (HAM) to government officials / law enforcers, and the obligation to enforce is the obligation to take steps to investigate and proceed with legal proceedings in the event of human rights violations. Human rights are basic rights inherent by nature in every human being, universal and lasting. Therefore, human rights must be respected, promoted, fulfilled and enforced. Human rights are not new to the Indonesian people. ${ }^{2}$

Legal protection must take into account the stages, namely legal protection born from a legal provision and all legal regulations provided by the community which are basically a community agreement to regulate the behavioral relationships between community members and between individuals and the government which are considered to represent the interests of the community. ${ }^{3}$

According to Satjipto Rahardjo, legal protection is to provide protection for human rights (HAM) that are harmed by others and this protection is given to the community so that they can enjoy all the rights provided by law. ${ }^{4}$ The objectives of the Unitary State of the Republic of Indonesia as stated in the Fourth Paragraph of the Preamble of the 1945 Constitution of the Republic of Indonesia, identifies that the Indonesian state is a country adhering to the concept of a welfare state. ${ }^{5}$

J.Barent in his book Der Wetenschap der Politiek argues that the real purpose of the State is maintenance, namely the maintenance of order, security, and the administration of public welfare in the broadest sense. ${ }^{6}$

Rule of law theory requires that state power-holding institutions exercise their power under legal control. State functions are determined by the types of countries adopted. Generally, countries with a formal (classical) legal ideology recognize the type of capitalistic individualist liberal state, so that in its realization, this type of state merely acts as a night watchman (nachtwachter-staat, Nachwachter). ${ }^{7}$ Article 1 paragraph (3) of the 1945 Constitution affirms that the state of Indonesia is a constitutional state, meaning that all structures of life as nation, society and state are based on law. The rule of law statement is then marked by the existence of a judiciary with the task of enforcing the rule of law. ${ }^{8}$ Welfare State is a form of society characterized by a democratic welfare system supported by the government which is placed on a new basis, providing a guarantee of collective social care to its citizens. ${ }^{9}$ The concept of a welfare law state

\footnotetext{
2 Sinaga, e. j. (2016). jurnal ilmiah kebijakan hukum. p.142.

3 Satjipto Raharjo. (2000). Ilmu Hukum, Bandung : PT. Citra Aditya Bakti. p. 53

4 Ibid, p. 69

5 Sri Rahayu, Rakhmat Bowo Suharto. (2017). Tugas Dan Pelaksanaan Wewenang Dewan Perwakilan Rakyat Daerah (Dprd) Dalam Mengadvokasi Aspirasi Petani Melalui Pembentukan Peraturan Daerah (Perda) Perlindungan Dan Pemberdayaan Petani Di Kabupaten Banjarnegara, Jurnal Hukum Khaira Ummah Vol. 12. No. 3 September 2017, p. 445

6 Ibid, p. 51

7 E. Utrecht. (1985). Pengantar Hukum Administrasi Negara. Jakarta: Ichtiar Baru. p. 3-4.

${ }^{8}$ Article 1 paragraph (3) of the 1945 Constitution

9 Piet Thoenes, "The Elite in The Welfare State", cited Mustaming Daeng Matutu, selayang pandang (tentang perkembangan Type-type Negara Modern, Pidato pada lustrum ke IV Fakultas hukum dan Pengetahuan Masyarakat Universitas Hassanuddin di Makasar, 3 March 1972, Hasanuddin University Press,Ujung Pandang, cetakan ke II, p. 20, see La Ode Husen, (2005). Hubungan Fungsi Pengawasan DPRdengan BPK Dalam Sitem Ketatanegaraan Indonesia, Bandung: CV Utama, p. 23.
} 
is often referred to as a modern legal state in a material sense. Bagir Manan said that the concept of the welfare law state is: "The state or government is not merely a guardian of security or public order, but the main bearer of the responsibility to realize social justice, public welfare, and the greatest prosperity of the people".10

Based on the description above, the purpose of this study is to identify and analyze indicators the realization of a welfare state law through development program documents and the implementation of human rights.

\section{Research Methods}

The approach method used is normative juridical, namely legal research that places law as a norm system building. The norm system in question is about the principles, norms, rules of legislation and doctrine. Normative juridical research examines the rule or rule of law as a building system associated with certain legal events. The type of data used in this study is secondary data consisting of primary legal materials, secondary legal materials, and tertiary legal materials. ${ }^{11}$

\section{Results and Discussion}

Indicator The manifestation of a welfare law state can be found through the document on the Development Program and the Implementation of Human Rights found at Regional development planning documents consist of RPJPD, RPJMD and RKPD which contain the vision, mission, policy direction and main targets of regional development.

\subsection{RPJPD (Long Term Regional Development Plan)}

Long-term Regional Development Plan, hereinafter referred to as RPJPD, is a Regional planning document for a period of 20 (twenty) years ${ }^{12}$. In Article 263 paragraph 1 that the Regional development planning document consists of RPJPD, RPJMD and RKPD. The RPJPD is an elaboration of the vision, mission, policy direction and main targets of long-term Regional development for 20 (twenty) years which is compiled based on the RPJPN and regional spatial planning. The RPJPD becomes a guide in the formulation of the vision, mission and programs of regional head candidates, as the social contract theory put forward by John Locke, and also Rousseau, which states that the state obtains power from citizens as the holder of sovereignty solely to respect, protect and fulfill rights. - the rights of citizens, this theory is in line with Article 1 paragraph 2 of the 1945 Constitution of the Republic of Indonesia which states that sovereignty is in the hands of the people and implemented according to the Constitution, in this case the objectives

\footnotetext{
10 Bagir Manan. (1996). Politik Perundang undangan dalam Rangka Mengantisipasi Liberalisme Perekonomian, FH UNLA, Bandar Lampung, p. 9

11 Widayati. (2020). Implementasi Asas Hukum Dalam Pembentukan Peraturan Perundang-Undangan Yang Partisipatif Dan Berkeadilan, Jurnal Hukum Unissula volume 36 no. 2, p. 61

12 Law of the Republic of Indonesia Number 23 of 2014 concerning Regional Government Article 1 number 27
} 
of the state as stated in the preamble to the 1945 Constitution, namely to protect the entire Indonesian nation and all Indonesian bloodshed and to promote public welfare, educate the nation's life and participate in implementing world order. The social contract between the state and Indonesian citizens is contained in the vision and mission of the President of the Republic of Indonesia as outlined in Nawacita contains 9 (nine) priority change agendas in the context of realizing an Indonesia that is sovereign, independent and has personality. Vision and missionalso includes the President's policies in overcoming problems in the field of human rights. Social contractamong residents in the Regency / City area are also contained in the Regent / Mayor's Vision and Mission, to clarify the direction of the realization of the said development vision, then formulated in a priority agenda, for example in one area an elected Mayor proclaimed the philosophy of "Brayan Urip" with implementation indicators consisting of :

- Fulfillment of basic needs in the fields of education, health, a livable environment and other needs.

- Increasing the role of facilitation for all parties to be involved in urban development in the political, economic, social and cultural fields through the provision of services, information, infrastructure and capacity building.

- Open up as much space for participation as possible for all stakeholders in the preparation of development plans.

- Open a room for checks and balances by both the media and the public.

- Improve people's welfare through creative city infrastructure, climate and creative economy development.

Regional governments in making their development plans are required to prepare 6 (six) types of planning and budgeting documents, namely RPJPD, RPJMD, Regional Spatial Planning (RTRW), Strategic Plans (Renstra) of Regional Work Units (SKPD), Regional Development Work Plans (RKPD) and SKPD Work Plan (Renja SKPD). In terms of time, these documents can be divided into three, namely long-term planning documents (20 years) consisting of RPJPD and RTRW, medium-term planning documents (5 years) which include RPJMD and Renstra SKPD, as well as a short-term planning document (1 year) which includes the RKPD and Renja SKPD. The RPJPD is the direction, goals and conditions desired in the long term of regional development as outlined in the vision, mission and direction of long-term regional development policies. The Development Program prepared by the Regional Head must be guided by the RPJPD by taking into account the RPJMN. The RPJMD is spelled out in the RKPD and becomes the guideline for SKPD in preparing the Strategic Plan, Renja and Work Plan and Budget (RKA). From the RKPD and RKA SKPD, the Regional Revenue and Expenditure Budget Plan (RAPBD) is prepared. RPJMD (Regional Medium Term Development Plan) ${ }^{13}$.

\subsection{RPJMD (Regional Medium Term Development Plan)}

Medium Term Regional Development Plan (RPJMD) is a Regional planning document for a period of 5 (five) years. The RPJMD is an elaboration of the vision,

${ }^{13}$ Rpjpd Pekalongan City 2005-2025 p. 6 
mission and programs of the regional head which contains objectives, targets, strategies, policy directions, regional development and regional finance, as well as regional and cross-regional apparatus programs accompanied by an indicative funding framework for a period of 5 (five ) years compiled based on the RPJPD and RPJMN.

In the framework of the government system that has appointed elected Mayor and Deputy Mayor, where the election process has conveyed its vision and mission to the entire community, this vision is basically a vision that has been agreed upon to be realized at the end of the term of office of the Mayor and Deputy Mayor, in program 5 (five) years will be further broken down intoRegional Annual Development Plans, hereinafter referred to as Regional Government Work Plans (RKPD), are Regional planning documents for a period of 1 (one) year. The RKPD is an elaboration of the RPJMD which contains the draft regional economic framework, regional development priorities, as well as a work plan and funding for a period of 1 (one) year which is compiled by referring to the Government Work Plan and national strategic programs stipulated by the Central Government.

\section{Conclusion}

The conclusion of this research is that the welfare law state is often referred to as a modern law state in a material sense in the sense that the State or government is not merely the guardian of security or public order, but is the main bearer of the responsibility for realizing social justice, public welfare, and as much prosperity as possible. the people, as The social contract theory was put forward by John Locke, and also Rousseau, who stated that the state obtained power from citizens as the holder of sovereignty solely to respect, protect and fulfill the human rights of citizens, this theory is in line with Article 1 paragraph 2 of the Law The 1945 Constitution of the Republic of Indonesia states that sovereignty is in the hands of the people and implemented according to the Basic Law, the embodiment of the welfare state stated in the preamble to the 1945 Constitution, namely protecting the entire Indonesian nation and all Indonesian bloodshed and to promote public welfare, educate the nation's life and participate in implementing world order, This national goal contains the vision of the Indonesian people in the field of human rights and subsequently brought down in the vision and mission stated in the Regional Long-Term Development Plan (RPJPD) and the Regional Medium-Term Development Plan (RPJMD) which contain the vision and mission which can be an indicator of the realization of a welfare state law.

\section{References}

\section{Journals:}

[1] Widayati. (2020). Implementasi Asas Hukum Dalam Pembentukan Peraturan Perundang-Undangan Yang Partisipatif Dan Berkeadilan, jurnal hukum unissula volume 36 no. 2,

[2] Sri Rahayu, Rakhmat Bowo Suharto. (2017). tugas dan pelaksanaan wewenang dewan perwakilan rakyat Daerah (dprd) dalam mengadvokasi 
aspirasi petani melalui Pembentukan peraturan daerah (perda) perlindungan dan Pemberdayaan petani Di kabupaten banjarnegara, Jurnal Hukum Khaira Ummah Vol. 12. No. 3 September 2017,

[3] Piet Thoenes, "The Elite in The Welfare State", cited from Mustaming Daeng Matutu, selayang pandang (tentang perkembangan Type-type Negara Modern, Pidato pada lustrum ke IV Fakultas hukum dan Pengetahuan Masyarakat Universitas Hassanuddin di Makasar, 3 March 1972, Hasanuddin University Press,Ujung Pandang, cetakan ke II, p. 20, see La Ode Husen. (2005). Hubungan Fungsi Pengawasan DPRdengan BPK Dalam Sitem Ketatanegaraan Indonesia. Bandung: CV Utama

\section{Books:}

[1] Bagir Manan, 1996, Politik Perundang undangan dalam Rangka Mengantisipasi Liberalisme Perekonomian, FH UNLA, Bandar Lampung

[2] Tim ICCE UIN jakarta, 2003 Pendidikan Kewarganegaraan (Civic Education), Demokrasi, HAM dan Masyarakat Madani, Jakarta dan Prenada Media.

[3] sinaga, e. j. (2016). Jurnal ilmiah kebijakan hukum.

[4] Satjipto Raharjo. (2000). Ilmu Hukum, Bandung : PT. Citra Aditya Bakti.

[5] E. Utrecht. (1985). Pengantar Hukum Administrasi Negara. Jakarta: Ichtiar Baru

\section{Regulations:}

[1] Rpjpd Pekalongan City 2005-2025

[2] Law of the Republic of Indonesia Number 23 of 2014 concerning Regional Government Article 1 number 27

[3] Article 1 paragraph (3) of the 1945 Constitution 